3 Gordon T, Kannel WB, Hjortland MC, McNamara MP. Menopause and coronary heart disease: the Framingham study. Ann Intern Med 1978;89:157-61.

4 Witteman JCM, Grobee DE, Kok FJ, Hofman A, Valkenburg HA. Increased risk of atherosclerosis in women after the menopause. Br Med f 1989;298:642-4

5 Witteman JCM, Kok FJ, van Saase JLCM, Valkenburg HA. Aortic calcification as a predictor of cardiovascular mortality. Lancet 1986;ii: $1120-2$.

6 Ross RK, Paganini-Hill A, Mack TM, Arthur M, Henderson BE. Menopausal oestrogen therapy and protection from death from ischaemic heart disease. Lancet 1981;i:858-60.

7 Stampfer MJ, Willett WC, Colditz GA, Rosner B, Speizer FE, Hennekens CH. A prospective stud of post menopausal estrogen therapy and coronary heart disease. $N$ Englf $M e d$ 1985;313:1044-9.

8 Paganini-Hill A, Ross RK, Henderson BE. Postmenopausal oestrogen treatment and stroke: prospective study. $\mathrm{Br}$ Med $\mathcal{F}$ 1988;297:519-22.

9 Lind T, Cameron EC, Hunter WM, et al. A prospective controlled trial of six forms of hormone replacement therapy given to postmenopausal women. Br $\mathcal{F}$ Obstet Gynaecol 1979;86 (suppl 3): $1-29$

10 Hunt K, Versey M, McPherson K, Coleman M. Long-term surveillance of mortality and cance incidence in women receiving hormone replacement therapy. Br 7 Obstet Gynaecol 1987;94: 620-35.

11 Riggs BL, Melton LJ III. Involutional osteoporosis. $N$ Engl f Med 1986;314:1676-86.

12 Weiss NS, Ure CL, Ballard JH, Williams AR, Daling JR. Decreased risk of fractures of the hip and lower fore-arm with postmenopausal use of estrogen. N Engl f Med 1980;303:1195-8.

13 Munk-Jensen N, Nielsen SP, Obel EB, Eriksen PB. Reversal of postmenopausal vertebral bone loss by oestrogen and progestogen: a double blind placebo controlled study. Br Med 1988:296:1150-2.

14 Paganini-Hill A, Ross RK, Gerkins VR, Henderson BE, Arthur M, Mack TM. Menopausal estrogen therapy and hip fractures. Ann Intern Med 1981;95:28-31.

5 Ettinger B, Genant HK, Cann CE. Long-term estrogen replacement therapy prevents bone loss and fractures. Ann Intern Med 1985;102:319-24.

16 Purdie DW. Broken bones-a gynaecological problem. Br f Obstet Gynaecol 1988;95:737-9.
17 Horsman A, Marshall DH. Age-related bone loss and fracture risk: a stochastic model. Mathematical Modelling 1986;7:991-1001.

18 Kanis JA, Passmore R. Calcium supplementation of the diet 1. Br Med 7 1989;298:137-40.

19 Kanis JA, Passmore R. Calcium supplementation of the diet. II. Br Med f 1989;298:205-8.

20 Horsman A, Gallagher JC; Simpson M, Nordin BEC. Prospective trial of oestrogen and calcium in postmenopausal women. BrMed $\mathcal{F}$ 1977; ii: 789-92.

21 Riis B, Thomsen K, Christiansen C. Does calcium supplementation prevent postmenopausal bone loss? N Engl f Med 1987;316:173-7.

22 Ziel HK, Finkle WD. Increased risk of endometrial carcinoma among users of conjugated estrogens. N Engl f Med 1975;293:1167-70.

23 Mack TM, Pike MC, Henderson BE, Pfeffer RI, Gerkins VR, Arthur M. Estrogens and endometrial cancer in a retirement community. $N$ Englf $\mathrm{Med}$ 1976;294:1262-7.

24 Kaufman DW, Miller DR, Rosenberg L, et al. Noncontraceptive estrogen use and the risk of breast cancer. FAMA 1984;252:63-7.

25 Key TJA, Pike MC. The role of oestrogen and progestagens in the epidemiology and prevention of breast cancer. Eur 7 Cancer Clin Oncol 1988;24:29-43.

26 Savvas M, Studd JWW, Fogelman I, Dooley M, Montgomery J, Murby B. Skeletal effects of oral oestrogen compared with subcutaneous oestrogen and testosterone in postmenopausal women. BrMed 7 1988;297:331-3.

27 Powers MS, Schenkel L, Darley PE, Good WR, Balestra JC, Place VA. Pharmacokinetics and pharmacodynamics of transdermal dosage forms of 17B-estradiol: comparison with conventional oral estrogens used for hormone replacement. Am f Obstet Gynecol 1985;152:1099-106.

28 Chow R, Harrison JE, Notarius $\mathrm{C}$. Effect of two randomised exercise programmes on bone mass of healthy postmenopausal women. $\mathrm{BrMed} \mathcal{f}$ 1987;295:1441-4.

29 Schapira D. Physical exercise in the prevention and treatment of osteoporosis-a review. $\mathcal{R} R \mathrm{Soc}$ Med 1988;81:461-3.

30 Cooper C, Barker DJP, Wickham C. Physical activity, muscle strength, and calcium intake in fracture of the proximal femur in Britain. Br Med f 1988;297:1443-6.

\title{
Hypercalcaemia in malignancy
}

\section{Fluids and bisphosphonate are best when life is threatened}

Malignancy accounts for about half of the cases of hypercalcaemia seen in hospital, ${ }^{12}$ and around $5 \%$ of hospital patients with a malignancy have complicating hypercalcaemia. Carcinomas of the breast and lung account for nearly half of cases. About three quarters of those with hypercalcaemia have overt disseminated disease, and about four fifths die within a year. In only four of 219 consecutive patients whom we studied was hypercalcaemia recognised before malignant disease - and in three of them the malignancy was discovered immediately the patient was investigated. ${ }^{2}$ Malignancy is only rarely the cause of hypercalcaemia in a patient who is well and is found by chance to be hypercalcaemic.

The symptoms of hypercalcaemia in malignancy are similar to those in other causes of hypercalcaemia, ${ }^{2}$ being non-specific and including fatigue, anorexia, constipation, polydipsia, muscle weakness, nausea, and vomiting. Many of the symptoms may easily be attributed to the malignancy itself or to its treatment. Many patients with hypercalcaemia complicating a malignancy do not receive treatment for it, and when they do it is commonly not the most effective.

Despite the many previous theories of how malignancy causes hypercalcaemia only two survive: the production of a protein like parathyroid hormone by the tumour and the release of bone resorbing cytokines from secondary tumours in the bone. The hypercalcaemias of malignancy and hyperparathyroidism have many biochemical similarities, ${ }^{3}$ but parathyroid hormone itself is rarely if ever produced by malignant tumours. But much evidence supports the production of a factor like parathyroid hormone, and two groups have now isolated a novel protein that acts like parathyroid hormone but is immunologically distinct. ${ }^{+5}$

Unfortunately, many different names have been attached to the protein; it is referred to here as parathyroid hormone related protein. It consists of a 141 amino acid polypeptide whose initial 13 amino acids show a $61 \%$ homology with parathyroid hormone; other areas of the molecule show little if any homology. All the known biological activity of the protein resides in the first 34 amino acids, and synthetic analogues of the 1-34 fragment of the protein as well as the entire molecule have all the biological actions of para- thyroid hormone: they are usually at least as potent as parathyroid hormone-and in some assays are more so..$^{6-8}$ Parathyroid hormone related protein is particularly potent when given parenterally. The protein has been identified in a wide range of solid tumours complicated by hypercalcaemia, and antibodies to it alleviate hypercalcaemia in animal models of hypercalcaemia of malignancy. ${ }^{9}$ It is probably responsible for the hypercalcaemia of many or most of the patients seen in clinical practice.

Several bone resorbing cytokines have now been identified, including interleukin-1, ${ }^{10}$ transforming growth factors, ${ }^{11} 12$ epidermal growth factor, ${ }^{13}$ tumour necrosis factor, ${ }^{14}$ and platelet derived growth factor. ${ }^{15}$ In addition, prostaglandin $\mathrm{E}_{2}$ resorbs bone in vitro. ${ }^{16}$ Except under exceptional circumstances none of these factors causes hypercalcaemia when given parenterally. But many are produced by tumours and if produced locally in bone from metastases they might cause appreciable osteolysis and release calcium into the circulation. Yet there is no correlation between hypercalcaemia and the number of bone metastases. If, therefore, locally active cytokines are produced by many secondary tumours in bone the body may be able to eliminate the calcium released and prevent hypercalcaemia.

The two hypotheses may be combined to explain most circumstances in which hypercalcaemia occurs. Many tumours (particularly those of epithelial origin) produce parathyroid hormone related protein. To begin with not enough is produced to cause hypercalcaemia, but occasionally sufficient is secreted, and hypercalcaemia and rarely "hyperparathyroid bone disease" result. ${ }^{17}$ Increased tumour mass leads to greater production of the protein and a greater chance of hypercalcaemia. Secondary tumours in bone release locally active cytokines that cause osteolysis. Under normal circumstances the excess calcium is excreted, but if the tumour also produces parathyroid hormone related protein the two mechanisms will be additive and make it much more difficult for normocalcaemia to be maintained.

All patients with a malignancy who feel unwell should have their serum concentrations of calcium and albumin or total protein measured. Measuring albumin and total protein 
concentrations is important as hypoalbuminaemia is common in malignancy and if present will mean that the total serum calcium concentration underestimates the severity of the hypercalcaemia. If the patient is known to have a malignancy the hypercalcaemia will not usually require further investigation. In patients found to be hypercalcaemic who have a history of malignancy investigation is essential before recurrence of the malignancy is assumed. The new assays for parathyroid hormone almost invariably show low or low normal serum concentrations in malignancy whereas in hyperparathyroidism these are usually increased. ${ }^{18}$

Hypercalcaemia may be severe and life threatening and associated with appreciable symptoms or mild to moderate, commonly without symptoms. Each requires different treatment. Severe, life threatening hypercalcaemia should be diagnosed not only from the serum concentration of calcium (which will usually be above $3.5 \mathrm{mmol} / \mathrm{l}$ ) but also from the clinical features. Not all patients with severe hypercalcaemia should be treated. The decision to treat will depend on the recent quality of life, current symptoms, and the prospect of further treatment of the malignancy. Once a decision to treat has been made rapid correction of the hypercalcaemia over hours should be avoided as it seems to be dangerous.

The object of treatment is to correct dehydration, which often causes an appreciable improvement on its own, and to prescribe a drug that will have a high chance of bringing the serum calcium concentration to normal or near normal values within 24-48 hours afterwards. Although corticosteriods and calcitonin remain the most commonly used drugs, there is little published evidence to support their use. Except in some haematological malignancies corticosteroids are ineffective, ${ }^{19} 20$ and calcitonin has only a modest early effect in some patients. ${ }^{21}$ Current evidence overwhelmingly supports using an intravenous bisphosphonate drug (previously termed diphosphonate), of which only one, disodium etidronate, is currently licensed for use in hypercalcaemia.

For this reason the policy I have used for treating severe hypercalcaemia of malignancy is to give 2-3 litres of intravenous fluids each day with potassium supplements combined with daily infusions of disodium etidronate $7.5 \mathrm{mg} / \mathrm{g} /$ day for three days. ${ }^{22}$ Such a regimen is simple and almost always effective. Once the hypercalcaemia has been controlled much will depend on whether any effective treatment may be given to control the malignant process. Without such treatment hypercalcaemia often recurs within weeks.

An oral treatment that could be given to outpatients would be highly desirable for treating those with mild to moderate hypercalcaemia of malignancy, but unfortunately this is not available. Oral phosphate is effective in most patients but is tolerated by only a few; oral glucocorticoids are tolerated but are effective in only about a third of patients. ${ }^{23}$ Prostaglandin synthetase inhibitors are ineffective, as is cellulose phosphate. The only oral bisphosphonate available for prescription (disodium etidronate) does not seem to be effective; other oral bisphosphonates that are effective but not currently available are likely to be the best treatment in the future.

D A HEATH

Reader in Medicine,

Department of Medicine,

Queen Elizabeth Hospital,

Birmingham B15 2TH

1 Fisken RA, Heath DA, Bold AM. Hypercalcaemia - A hospital survey. $Q \mathcal{f}$ Med 1980;49:405-18.

2 Fisken RA, Heath DA, Somers S, Bold AM. Hypercalcaemia in hospital patients. Clinical and diagnostic aspects. Lancet 1981;i:202-7.

3 Heath DA. Hypercalcaemia and malignancy. Ann Clin Biochem 1976;13:555-60.

4 Suva LJ, Winslow GA, Wettenhall REH, et al. A parathyroid hormone-related protein implicated in malignant hypercalcemia: cloning and expression. Science 1987;237:893-6.

5 Mangin M, Webb AC, Dreyer BE, et al. Identification of a cDNA encoding a parathyroid hormonelike peptide from a human tumor associated with humoral hypercalcemia of malignancy. Proc Natl Acad Sci USA 1988;85:597-601.

6 Horiuchi N, Caulfield MA, Fisher JE, et al. Similarity of synthetic peptide from human tumor to parathyroid hormone in vivo and in vitro. Science 1987;238:1566-8.

7 Kemp BE, Moseley JM, Rodda CP, et al. Parathyroid hormone-related protein of malignancy; active synthetic fragments. Science 1987;238:1568-70.

8 Thorikay H, Kramer S, Reynolds FH, et al. Synthesis of a gene encoding parathyroid hormone-like protein (1-141): purification and biological characterisation of the expressed protein. Endocrinprotein $(1-141)$ : purice

9 Kukreja SC, Shevrin DA, Wimbiscus S, et al. Antibodies to parathyroid hormone-related protein lower serum calcium in athymic mouse models of malignancy-associated hypercalcemia due to lower serum calcium in athymic mouse models

10 Gowen M, Wood DW, Ihrie EJ, McGuire MKB, Russell GG. An interleukin-1 like factor stimulates bone resorption in vitro. Nature 1983;306:378-80.

11 Ibbotson KJ, Twardzik DR, D'Souza SM, Hargreaves WR, Todaro GJ, Mundy GR. Synthetic transforming growth factor alpha stimulates bone resorption in vitro. Science 1985;228: 1007-9.

12 D'Souza SM, Ibbotson KJ, Smith DD, Mundy GR. Production of a macromolecular bone resorbing factor by the hypercalcemic variant of the Walker rat carcinosarcoma. Endocrinology 1984;115:1746-52.

13 Tashjian AH Jr, Levine L. Epidermal growth factor stimulates prostaglandin production and bone resorption in cultured mouse calvaria. Biochem Biophys Res Commun 1978;85:966-75.

14 Bertolini DR, Medwin GE, Bringman TS, Smith DD, Mundy GR. Stimulation of bone resorption and inhibition of bone formation in vitro by human tissue necrosis factor. Nature 1986;319:516-8.

15 Tashiian $\mathrm{AH} \mathrm{Jr}, \mathrm{Hohmann} \mathrm{EL}$ Antoniades $\mathrm{HN}$, Levine L. Platelet derived growth factor Thimulases bone resorption 111:118-24.

16 Klein DC, Raisz LG. Prostaglandins; stimulation of bone resorption in tissue culture. Endocrinology 1970;86:1436-40.

17 Loveridge N, Kent GN, Heath DA, Jones EL. Parathyroid hormone-like bioactivity in a patient with severe osteitis fibrosa cystica due to malignancy: renotrophic actions of a tumour extract as

18 Brown RC, Aston JP, Weeks I, Woodhead JS. Circulating intact parathyroid hormone measured by a two-site immunochemiluminometric assay. F Clin Endocrinol Metab 1987;65:407-14.

19 Thalassinos NC, Joplin GF. Failure of corticosteroid therapy to correct the hypercalcaemia of malignant disease. Lancet 1970;ii:537-9.

20 Percival RC, Yates AJ, Gray RE, Neal FE, Forrest ARW, Kamis JA. Role of glucocorticoids in management of malignant hypercalcaemia. BrMed f 1984;289:287.

21 Hosking DJ, Gilson D. Comparison of the renal and skeletal actions of calcitonin in the treatment of severe hypercalcaemia of malignancy $Q \mathcal{J}$ Med 1984;211:359-69.

22 Hasling $C$, Charles $P$, Mosekilde L. Etidronate disodium in the management of malignancy related hypercalcemia. $A m$ F Med 1987;82(suppl 214):51-4.

23 Mundy GR, Wilkinson R, Heath DA. Comparative study of available medical therapy for hypercalcemia of malignancy. Am f Med 1983;74:421-32.

\section{Difficulties raised by insurance medical reports}

\section{Make sure patients have given consent and avoid conjecture}

Doctors have been helping insurance companies and patients by completing "personal medical attendants' reports" for insurance policies since the last century. This process has worked well-so long as safeguards recommended in the BMA's Handbook of Medical Ethics ${ }^{1}$ are followed-but now AIDS is presenting new problems. Insurance companies are anxious to pick up on anybody who might be infected with HIV, and patients are disturbed by their doctors being asked very personal questions about them.

In the past doctors have acted in the best interest of patients even when reporting adverse features of their medical histories - because if an incorrect statement or relevant fact is overlooked then insurers may reject a claim and the patient may forfeit paid premiums. Now, because of AIDS, insurance companies have included questions in the personal medical attendants' reports about possible contact with sexually transmitted diseases, which are upsetting both doctors and patients. And the Medical Reports Act, which came into force at the beginning of the year, will mean that patients have access to what doctors say about them in their medical reports.

A study from Hampshire reported on p 1495 showed that 